\title{
Forms of knowledge and the love of necessity in Bourdieu's clinical sociology
}

Geoffrey Mead

The Sociological Review [submitted version]

\begin{abstract}
The potential for sociological knowledge to assist in counteracting deleterious social forces remains a live question. In the present article I approach this question from the perspective of the work of Pierre Bourdieu, and offer an explication of what can be called Bourdieu's ‘clinical sociology'. This approach presents specifically personal modes of 'counteracting’ those social forces that entrench themselves in the body. I begin by examining the central position, within Bourdieu's philosophical anthropology, of knowing the world as the primordial mode of engaging with it. The clinical task begins with people coming, reflexively, to know what they know. Once they appropriate this knowledge, it becomes possible either to labor on overcoming this knowledge, by a form of bodily re-learning, or to relent to the necessity of a world that they lucidly know extends beyond their capacity to amend.
\end{abstract}

\section{Introduction}

A contentious paradox cuts through Pierre Bourdieu's oeuvre. The sociologist tells us that by elucidating the very 'laws' that curtail freedom, he actually makes attempts to expand this freedom more likely (Bourdieu 1993: 25). Specifically, Bourdieu asserts that by knowing these laws we are better positioned to labor on subverting them than if they were not known: ‘determined...man can know his determinations and work to overcome them’ (2000a: 131). Commentators have responded in a range of ways to this proposition: from Rancière's (2012: 12) dismay that 'if the dominated are dominated, it is because they are unaware of the laws of 
domination'; to Boltanski’s (2011: 19) postulation that identifying determinations without specifying their normative significance amounts to little; and finally to Hilgers’ (2009) almost open embrace of the claim. By attending to the philosophical and conceptual underpinnings of Bourdieu's proposition, I suggest that such commentary, whether it disputes or affirms the truth of the claim, treats merely one dimension of it: the properly political one, premised on a specifically collective knowledge of social laws.

In contrast, I will assert the utility of what Bourdieu described as a 'purely personal and quasi-clinical application of sociology’ (in Mauger and Pinto 1994: 318), which Frangie (2009: 219) describes as the 'counterpart of Bourdieu's Realpolitik of reason', and which develops along with the latter throughout the 1980s and 1990s (see Bourdieu 2008: 222). Furthermore, this distinctly personal approach serves to complement those interpretations of Bourdieu's work that inquire into the relations between its theoretical commitments and those of psychoanalysis (Darmon 2016; Fourny 2000; Steinmetz 2013). Pressing this point further, I wish to sketch the framework for a 'quasi-clinical application of sociology'. Bourdieu's work can, then, be shown to complement the approach espoused by clinical sociologists (see Gaulejac 1997). As I will depict it here, Bourdieu's particular clinical sociology demands reflexive attempts to identify and unearth a profound practical knowledge of the social world and one's position within it. Given the emphasis that Bourdieu places on a specifically bodily knowledge, the application is centered on unearthing knowledge lodged within the body, resulting in what he describes as a 'bodytherapy', 'a therapy by gymnastics' (Bourdieu 2000b: 13).

In making these suggestions, my intentions are to explicate and to begin to systematize the 'clinical uses' of Bourdieu's sociology (2000b: 13), by attending to the identifiable philosophical underpinnings of these uses. It is thus that there emerges a novel approach to 
the vexed issue of whether Bourdieu's vision of society permits change. In particular, I offer a response to such a position as that espoused by Bohman (1999: 136), who skeptically asks whether Bourdieu's actors, or 'agents', 'can begin to reflect upon and thus to transform the dispositions they have been socialized into, at least one at a time'. While asserting through my account of the clinical uses of sociology that indeed they can, I also furnish an account of those instances in which there is little objective scope for actors to seek change, at least personally. Here, while social necessity is overwhelming, agents are able to seek justifications for existing not by escaping necessity, but by embracing - and even loving - it. This represents a revalorization of the notion of 'amor fati' that Bourdieu undertakes intermittently in his later work. In this way I offer an answer to Rancière's (2003: 180) question: 'What can one do with...a science of relations of power that says these are infrangible?’.

I take my point of departure in a topic of importance within debates concerning 'critical sociology': that is, the status and character of knowledge, particularly as it appears in Bourdieu's work. My argument emerges from the perspective of his philosophical anthropology: Bourdieu's social agents fundamentally engage with the world by knowing it (mostly in an 'implicit' or 'bodily' sense). This underlies Bourdieu's concept of the habitus. As he puts it, by virtue of the internalization of the social world, crystallized in the form of habitus, 'I know confusedly what depends on me and what does not, what is "for me" or "not for me" or "not for people like me", what it is "reasonable" for me to do, to hope for and ask for' (Bourdieu 2000a: 130). I will explore the political implications of such a conception, in which a social agent is presumed to be coextensive with her knowledge of the world. Next, I make recourse to the work of Merleau-Ponty and to Plato's Meno dialogue both to trace the philosophical import of Bourdieu's conception of knowledge and to begin sketching what is implied by a ‘clinical sociology’ in Bourdieu’s mode. In particular, the character of Socrates 
is shown to offer a symbol for the Bourdieusian sociologist, whose clinical role is ostensibly analogous to Socrates', permitting the 'reappropriation' of knowledge already possessed as a means of reflecting on it. I then proceed to explore and reconstruct the logic underlying the clinical application, arguing that it is geared toward an attempt to reconstruct practical knowledge, rather than to nullify it by means of conscious reflection. Finally, I treat an instance in which practical knowledge is not reconstructed and social agents yield to the necessity of a world they cannot change. This is an instance in which love is valorized. Yet far from being a simple submission to the world, Bourdieu presents love as offering forms of recognition autonomous from those provided by the state.

\section{Forms of knowledge}

The importance that Bourdieu places on knowledge as the primary mode by which social agents engage with the social world is difficult to overstate. This is to say that in Bourdieu's philosophical anthropology, people relate to the world by knowing it, in a manner analogous to the relation of 'concern' that Dasein, for Heidegger, maintains with the world. Readers are exposed to this most prominently in his final summative statement on his corporeal philosophy, in Pascalian meditations (2000a), where he titles a chapter 'Bodily knowledge'. In the chapter, Bourdieu asserts that the body is an 'instrument of knowledge', rather than a hindrance, as the Cartesian method presents it (p.137). It functions as such an instrument, his argument continues, if one relinquishes the stereotype of knowledge as exclusively 'explicit' or codifiable (p.135). Rather, it is 'practical' and 'corporeal', proximate to what a number of philosophers, following Polanyi, call 'tacit' (Grene 1977). Importantly, for Bourdieu, this form of knowledge is qualitatively distinct and retains its own 'logic' (Bourdieu 1990a: 11).

To demonstrate the specificity of practical knowledge, Bourdieu appropriates Heidegger's famous example of practical dealings with a hammer. In his Collège de France lectures of the 
early 1980s, Bourdieu (2015) outlines the two relations that persist between habitus and world. The first of these is a relation of conditioning or incorporation, in which the world molds and constitutes the agent. The second, moving in the opposite direction, concerning the agent's relation to the world, is 'a relation of knowledge: the habitus suited to the hammer...is the one that is capable of hammering; the habitus is what responds appropriately to the solicitations of a social object. In this way, the habitus enters into a relation of knowledge with the object' (p.243). It follows that 'to strike with a hammer is an act of knowledge' (p.250), even if this knowledge seems so foundational that it passes without being recognized as one. Norbert Elias's (1994) account of the origins of the fork utensil functions as a reminder of the countless 'acts of knowledge' undertaken daily but not perceived as such. He writes that early adopters seemed pretentious for including the fork in their dining, especially since, initially, 'they were not very adept in the use of the instrument: at least it was said that half the food fell off the fork as it travelled from plate to mouth' (p.60). Elias's point here is that 'What we take entirely for granted, because we have been adapted and conditioned to this social standard from earliest childhood, had first to be slowly and laboriously acquired and developed by society as a whole' (p.60).

Such a focus on specific and concrete objects like hammers and forks, however, does something of a disservice to the objects intended as sociological phenomena. The kind of quotidian knowledge of concern to the sociologist, or at least the one who accepts Bourdieusian premises, is that of the 'structures' of the social world, its hierarchized regularities. As Bourdieu argues in Distinction, these are 'internalized' in the form of cognitive structures of preference (for a given consumer good, eg). These cognitive structures, profoundly attuned to the world that has generated them, enable, on account of the depth of the attunement, a form of 'knowledge without concepts' (1984: 470). The fact that social agents engage with the world primarily through knowledge now begins to take on its 
full significance, for one develops preference structures on the basis of knowledge acquired about the world and about what one is likely to be able to appropriate from it: 'I know confusedly what...is "for me" or "not for me" or "not for people like me”, (2000a: 130). Social agents, the argument implies, come to 'know their place'.

The agent's acquisition of 'a practical, bodily knowledge of her present and potential position in social space' (2000a: 184) is not politically neutral, since that which she already knows is not 'for her' is more likely to be relinquished in advance, on account of this knowledge (1974: 15). Such an act of knowledge - manifest most explicitly in the paradigmatic form, 'this is not for me' - is also, Bourdieu argues, a kind of unwitting assent to the social order: such an act of knowledge (connaissance) is, at the same time, 'an act of misrecognition [méconnaissance], implying the most absolute form of recognition [reconnaissance] of the social order' (Bourdieu 1984: 471). Indeed, Bourdieu writes that 'recognition of domination always presupposes an act of knowledge' (2001: 40). It presumes a 'very exact knowledge of one’s symbolic value' (1990a: 104), of one’s place, and as a corollary to this a willingness to step aside or exclude oneself from the appropriation of that which one 'knows' is not one's due. Crucially, a practical knowledge of the social world equates to knowledge of social divisions and limits. What is fundamentally at issue when we speak of knowledge is, then, the 'knowledge supplied by the incorporation of the necessity of the social world, especially in the form of the sense of limits' (2000a: 185).

Acts of knowledge of limits and boundaries are simultaneously acts of recognition of them, forms of implicit assent. For Bourdieu, the vital character of these limits is profoundly entrenched. As he writes, "what is and is not "for us" [is] a division as fundamental and as fundamentally recognized as that between the sacred and the profane' (Bourdieu 1990a: 64). In taking the division between 'for me' and 'not for me' as paradigmatic, Bourdieu evokes 
the interested, immanent, and perspectival nature of this practical knowledge. In doing so, the full effect is felt of Bourdieu's opting to characterize his approach by a 'practical' knowledge over a 'theoretical' knowledge. While social agents indeed know the world - 'more than any intellectual, more than any sociologist' (Bourdieu and Eagleton 1992: 118) - they know it practically rather than theoretically, that is, without the inclination to sketch its regions like a kind of social surveyor (Bourdieu 1984: 471). Rather, they know the world from their own perspectives: I know what is likely to befall me and those in proximate positions; other distinctions are obscure, lacking in vital character such that I am indifferent to them.

'Practical' or 'interested' knowledge, concerned as it is with those matters specific to the agent, does not, then, simply function to inform or elucidate, as does the scientific ideal of 'disinterested' knowledge, but to actively orient and motivate. It is, then, unashamedly practical. It has no interest in ascending to the sphere of the disinterested and detached. By accentuating its close ties to practical ends, the earlier analogies of Heidegger's hammer and Elias's fork acquire renewed pertinence, for practical knowledge is not a simple collection of facts retained for future recall, like a set of instructions. Rather, it is knowledge incarnate. Again, it helps to contrast it to 'explicit knowledge', a learned set of facts that does not encourage action in any particular direction. Practical knowledge, on the other hand, since it is constitutive of 'knowing subjects' themselves, is fundamental to their sense of orientation. It is coextensive with each agent, such that she does not stand apart from it. As Bourdieu (1990: 73) asserts, 'What is 'learned by body' is not something that one has, like knowledge [savoir] that can be brandished, but something that one is'.

The same distinction between the practical and the theoretical is at the core of the phenomenological tradition, with which Bourdieu remains in close dialogue and which to a great degree establishes his orientation. Merleau-Ponty (2012: lxxii), for instance, erects a 
distinction between a resolutely intellectualist approach - most clearly apparent in 'Descartes, and above all Kant, [who] freed [délié] the subject' - and what he considers his own worldly and bodily phenomenological approach. This is an effort on Merleau-Ponty's part to revitalize the worldly subject of knowledge, against the Cartesian conception, in which one 'ceases to exist in order to know' (p.220), aspiring instead to one in which 'to live is to know' (Claudel 1969: 56).

Bourdieu himself accommodates Merleau-Ponty's approach here, citing the latter approvingly: 'The agent engaged in practice knows the world but with a knowledge which, as Merleau-Ponty showed, is not set up in the relation of externality of a knowing consciousness' (2000a: 142). What he adopts from Merleau-Ponty, then, is a commitment to the worldliness of the inescapably incarnated knowing subject. Moreover, the peculiar genealogy of the concept of 'knowledge' (as connaissance) in Merleau-Ponty's work suggests something even more: that not merely are knowing subjects 'in the world', 'living in' a world they know, but that they are born with the world (1963: 197). Merleau-Ponty borrows here a fanciful etymology of the verb, 'connaître' (to know), from the poet Paul Claudel (1969). For Claudel, to know (connaître) the world is to be 'born with' it (co-naître): 'We are part of a homogeneous whole, and, as we are born with all that which is nature, we know it’ (1969: 46—translation modified). Bourdieu himself appropriates this play on words to accentuate the social agent's profound and precocious adhesion to the social 'game' that she takes for granted: 'one is born into the game, with the game.... As Claudel put it, “connaître, c’est naître avec”, to know is to be born with’ (Bourdieu 1990a: 67).

Supposing that knowledge is coextensive with one's acquired capacities, Bourdieu implies that to know it in the profound sense that the metaphor of internalization suggests is to unwittingly assent to its order. Those who know the world and their place in it to the extent 
that they are their knowledge of the world, dispense 'acts of misrecognition' of the arbitrariness of the game itself and of the distribution of chances of appropriating its spoils. This is the central problem that Bourdieu's clinical sociology faces, for if the issue were simply that social agents were poor in knowledge, this could be quite simply remedied, at least conceptually. Yet they in fact possess much knowledge. The problem is that the very knowledge they have of the world constitutes the reason for their bondage. It would seem then that the only means of emancipation is to uproot practical knowledge, which - to take Bourdieu on his own terms - maintains its specificity, such that any kind intellectual 'consciousness raising' would be impotent in its face. Is, then, the only way to combat this symbolic violence, on an individual level, to undertake a process similar to 'an athlete's training', 'a thoroughgoing process of countertraining, involving repeated exercises' (2000a: 172)?

In the next section I proceed to detail the philosophical significance of Bourdieu's focus on practical knowledge, emphasizing the reasons why Bourdieu attempts, in the manner of the phenomenologists, to distill the specificity of practical knowledge ('doxa') against theoretical knowledge ('epistême').

\section{Plato's Meno}

Plato's dialogues offer Bourdieu two opportunities: first, they furnish means of expressing the crucial opposition, consecrated and crystallized by Plato, between 'doxa' ('mere' opinion) and 'epistême' (rational knowledge). This opposition in some respects anticipates the framework for the opposition between 'practical' and 'theoretical' knowledge. Second, Plato's dialogues, in particular the Meno (and Thaeatetus), provide Bourdieu a fertile symbol for the 'clinical' sociologist. I refer to the Socrates of the Meno, who functions as a 'midwife' to knowledge unknowingly held: 
I could employ, to better convey what I have to say, the parable of Socrates and the young slave: I think that the sociologist is someone who, at the price of a labor of investigation, of interrogation, using tools, modern techniques, enables others to give birth to something they know without knowing they know it (Bourdieu 2002: 14-15)

It is important that these two opportunities that Plato's dialogues offer be kept together, for it is the very conception of knowledge put forth that makes possible the conception of the sociologist as 'midwife': something is known - in fact, as we shall see, for Plato, one is born with such knowledge - but it is not known that it is known. The process of coming to know that it is known is called 'anamnesis'.

In the Meno (Plato 1997), Socrates seeks to effect a 'recollection' (anamnēsis) of eternal truths in the mind of a slave boy amidst an investigation into the question, asked by a young aristocrat named Meno, of whether virtue can be taught. Socrates sets one of Meno's slave boys a math problem and eventually extracts a correct answer from him, an answer to a problem of a kind he could never before have been taught. This, for Socrates, demonstrates that the boy has '[found] the knowledge within himself' (85d4): 'And', Socrates continues, 'is not finding knowledge within oneself recollection?' (85d6-7). Socrates affirms that thus 'we do not learn, but what we call learning is recollection' (81e4). While mere 'right' opinion (orthe doxa) appears, outwardly, to manifest the same virtue as knowledge does, in this dialogue Socrates wishes to maintain that one should not mistake it for knowledge. The two differ in that doxa lacks the justification that comes with knowledge. A transition from doxa to epistemēe is, finally, proposed: opinions are worth little 'until one ties them down by (giving) an account of the reason why. And that, Meno, my friend, is recollection' (98a3-5).

Recollection or anamnesis is therefore bound tightly to this process of giving 'an account of the reason why' [aitias logismos]. We can begin to understand the specific meaning of the 
phrase by noting other ways it has been translated: 'explanatory reasoning’ (Scott 2006: 181) and 'reasoning out the explanation' (Day 1994: 250). Furthermore, Nehamas (1994: 240) describes Plato's 'knowledge' here as consisting in 'the ability to explain what one understands'. This process of explanation, in which the one explaining is not merely expressing but is also herself discovering, involves - to put it in Bourdieu's terms something like the transmutation of practical into theoretical knowledge. The sociological interview operates, then, as a kind of accompanied self-analysis where interviewees 'appropriate the inquiry for themselves and become its subjects' (Bourdieu 1999: 609). In this way it offers them 'an opportunity also to explain themselves in the fullest sense of the term' (p.615).

Yet we should not think that the explanatory process involves the simple replacement of the sociologist by the interviewee, as if the latter had suddenly and proficiently adopted a theoretical language. This is to misunderstand what is meant by casting the sociologist as 'midwife'. Anamnesis assumes a peculiar relation between those in dialogue. In particular, by rejecting the approach of the classical sophist, who 'treats his pupil as an empty receptacle to be filled from outside with the teacher's ideas' (Burnyeat 2012: 27), it does not presume the ignorance - in Bourdieu's case - of the social agent herself, the one who would otherwise be seen as being in need of 'consciousness provided by enlightened social scientists' (Latour 2005: 154). Since this social agent is endowed with a great deal of knowledge, the role of the sociologist is to render a particularly sociological appreciation of things already known, to 'deliver' agents of their knowledge by facilitating its articulation. What the sociologist offers then is not knowledge as such, but a means of re-construing knowledge already possessed. This 'means' is what is referred to as a 'sociological gaze': 'The task is to produce, if not a “new person”, then at least a “new gaze”, a sociological eye’ (Bourdieu and Wacquant 1992: 251). 
So, while Bourdieu clearly equates 'practical knowledge... with the orthe doxa of which Plato talks in Meno' (p.128), epistèmē should not be reduced to the explicit and codified knowledge of sociological discourse. Instead of transmitting explicit facts, the sociologist assists in the agent's appropriation of knowledge already known. As Bourdieu puts it, the intended effect of the sociological encounter is not 'the familiarity supplied by the acquisition of a simple knowledge (savoir), but the familiarity gained by that reappropriation of a knowledge (connaissance) that is both possessed and lost from the beginning, which Freud, following Plato, called “anamnesis”” (Bourdieu 2001: 55; see also Witz 2004). The point here is that the appropriation of such knowledge is not a theoretical exercise, persisting on the level of explicit discourse, but is itself practical. Likewise, in the last decades, Plato scholarship has distanced itself somewhat from the notion that epistēme is reducible to knowledge conceived as codified theoretical discourse (Benson 2000). Rather, as Burnyeat (1980: 186) suggests: 'Much of what Plato says about knowledge and its relation to true opinion falls into place if we read him...as elaborating a richer concept of knowledge tantamount to understanding'. Thus 'anamnesis' cannot be construed as mere explicit knowledge, like being 'informed' of some or another fact, such as 'because of your social position you prefer $x$ '. Simply transmitting such facts, augmenting the social agent's 'knowing that', hardly suffices to bring about understanding, as it is conceived in either Plato's ideal or Bourdieu's.

Just as the acquisition of 'practical knowledge' is not accomplished without a great degree of practice, or labor as Bourdieu suggests, likewise one does not painlessly acquire knowledge about this knowledge. Rather, it can be ventured that the realization or awareness of knowledge is not merely intellectual, but comes only from kinds of practical 'tests' that deform and reform knowledge previously acquired. Take for example a classroom exercise devised by a psychologist and mentioned by Bourdieu (2001: 27), which aims to bring about a realization that would remain superficial if simply transmitted discursively (Henley 1977: 
143). In the exercise, boys are asked to mimic various body postures and acts otherwise expected of women (including averting one’s gaze each time a man passes, grasping a fallen pen while keeping one's skirt closed, etc.). These serve as pragmatic tests that allow one to realize one’s knowledge in its very displacement.

\section{An exercise in conversion}

Bourdieu describes the adoption of a sociological gaze in strikingly religious terms, as being akin to a 'genuine conversion...a transformation of one's whole vision of the social world' (Bourdieu and Wacquant 1992: 251). Furthermore, he suggests that the sociological interview itself can be considered a 'spiritual exercise' for the interviewer, as it ideally involves the latter's forgetting of self as a means of seeing the world anew. In these final two sections, I wish to explore and systematize these and similar remarks. That is, once one has been delivered of one's embodied knowledge, what follows? Rather than postulate that freedom ought to be sought outside of habitus, by invoking something like a transcendent consciousness that would subvert dispositions, my interpretation strives to remain consistent with Bourdieu's principles: if the difficulty the social agent faces is the presence of 'embodied social forces that operate from within us’ (Bourdieu and Wacquant 1992: 198), then a conversion ought to be concentrated on means to institute novel forces rather than to dissolve forces altogether.

I construe this 'conversion' as a distinctly corporeal process, as the material counterpart to the sociologist's spiritual exercise. If, as Bourdieu argues, the latter requires the sociologist to adopt a 'forgetting of self', conversion requires that agents recollect (or 'unforget') themselves and seek something like a 'reconquest of the self' (Bourdieu 1996: 312). As a preliminary, it is important to note that the recollection and appropriation of knowledge does not entail some kind of omnipotence. Rather, it is tactical. It permits 'us to discern the sites 
where we do indeed enjoy a degree of freedom and those where we do not' (Bourdieu and Wacquant 1992: 199). This 'conversion' aspect of the clinical approach does not apply to those regions where, as a single social actor, one is effectively impotent. For these regions, what is important is the 'necessitating' aspect of the clinical approach, which I treat in the final section.

Bourdieu still proposes only a limited form of liberating action even within those restricted sites that do afford this kind of practice. He and Wacquant (1992: 199) express this in the following manner:

When you apply reflexive sociology to yourself, you open up the possibility of identifying true sites of freedom, and thus of building small-scale, modest, practical morals in keeping with the scope of human freedom which, in my opinion, is not that large.

Here we observe a parallel between Bourdieu's clinical sociology - alternatively labeled 'socioanalysis' - and Freudian psychoanalysis, which is famously similarly limited in its aspirations. Indeed, the two approaches hold much in common, with the early Bourdieu often seeming to imply that, by simply recollecting or recognizing a forgotten genesis, the social agent could effect a cathartic resolution, just as Freud and Breuer's Anna O. does: once the genesis of her hysteria was 'brought to verbal utterance the symptoms disappeared' (Breuer and Freud 2001: 34). Bourdieu (1990b: 183) himself likewise once suggested that 'knowledge by itself exercises an effect'. Gaulejac (2003: 82) recounts an instance in which Bourdieu describes just this position and implies his move away from it: 'I was for a long time like the young Freud. I thought for a long time that the raising of consciousness [la prise de conscience] sufficed'. What differentiates Bourdieu's two positions regarding the raising of consciousness - and what explains his numerous attempts to dismiss its political efficacy 
(2001: 40) - is that the latter is predicated on a conception of knowledge as merely explicit and transmissible. If knowledge is coextensive with our manner of being in the world, then in Bourdieu's view an 'enlightening' will be insufficient. What is required is a profound conversion of practical knowledge, conceived 'not as a sudden reversal, but as continual, progressive labor’ (Bourdieu in Mauger and Pinto 1994: 318).

It is in this continual labor that Bourdieu's most characteristic clinical contribution to sociology is to be found. In a manner typical of Bourdieu, the rhetorical incantation of labor ('travail') extends to this 'labor on the self' (Bourdieu 2000b: 13). To capture the force of this maneuver, we return to Elias's account of the acquisition of the fork in Western society. Elias's claim that, culturally, '[w]hat we take entirely for granted...had first to be slowly and laboriously acquired' converges with Bourdieu's claim that, personally, there operates a 'whole labor of socialization' (2000a: 194). The acquisition of any profound mode of being requires a labor that, when successful, does not appear as such. It is, nevertheless, 'a personal labor', and 'the work of acquisition is a labor of the "subject” on himself' (Bourdieu 1979: 4). Likewise, any emancipatory effort to deliberately counteract a cultural inheritance - whether vaunted or stigmatized - will involve such laboring, 'a thoroughgoing process of countertraining, involving repeated exercises’ (2000a: 172). Bourdieu speaks in distinctly corporeal terms, of 'rectifying the body' (2000b: 13) and voluntarily submitting it to new forms of discipline that 'inscribe in the body dispositions capable of thwarting the tendencies of nature and the routines of culture' (1991: 53).

Bourdieu gives only scant indications of the kinds of bodily interventions he has in mind. For example, in one interview, he seems to spontaneously invoke 'a bodytheraphy...a therapy by gymnastics, linked to the care of the self' (2000b: 13). ${ }^{1}$ He makes further reference to a girl's account of 'how the fact of having done gymnastics completely changed her relationship to 
boys'. Presumably, this entails a trained relaxation of the kinds of strict and demure bodily comportment ordinarily felt by women to be required and which are inculcated and reinforced from an early age (Martin 1998). This is 'bodytherapy' as a subversion of the existing order. Here, the social agent recognizes what is expected ('for her') and that this expectation is profoundly corporeally entrenched, yet transgresses nonetheless, accepting the bodily and emotional discomfort that comes with transgression.

While this bodily transgression can be deployed for subversive ends, as in the example above, it can also serve conformist ends. The same 'process of countertraining' can be geared toward appropriating those goods that one would otherwise have relinquished. This is what Bourdieu indicates when he mentions renouncing many of his earliest 'acquisitions, and not only a certain accent' (Bourdieu and Wacquant 1992: 204). Here, one does not seek to trouble established categories, but rather, despite recognizing them as 'arbitrary', seeks to adapt oneself to them. This use of freedom accepts a broadly sociological definition of human agency: assuming constraints to be objective and non-malleable, what can one do? Here, social agents, assenting to objective social divisions, labor to reach a normalized standard to which they have hitherto failed to measure up.

At this point the scope for personal freedom finds itself increasingly diminishing: from feeling like divisions present themselves to be subverted, to feeling like they are necessary and the body itself has to be transformed, to, finally, feeling like they are necessary and little can be done in response. Now we encounter a dimension of Bourdieu's sociology that receives little attention: 'necessitating'. The world is taken for granted and one accepts that one is helpless in its face. The response, in relinquishing freedom to change either the world or one's own position within it, is to absolve oneself of any burden or responsibility for one’s own misery. Bourdieu says that the sociological gaze in this case 'can give to those who 
suffer the means of mastering at least the representation that they have of what befalls them' (in Mauger and Pinto 1994: 318). It functions as 'a way, not of justifying the world, but of learning to accept a lot of things that might otherwise be unacceptable' (Bourdieu and Wacquant 1992: 199). In particular, while Bourdieu had for a long time seen 'amor fati', or the love of fate, as something to militate against, his comments on love betray a dawning ambivalence to it.

\section{Love of necessity}

At first glance, Bourdieu seems to cast love as little more than another means of acquiescing to symbolic violence. Romantic love, he tells us, is a 'way of loving one's destiny in someone else and so of feeling loved in one’s own destiny’ (Bourdieu: 1984: 243). Peering deeper, however, I wish to conclude by arguing that, for Bourdieu, love functions as a clinical strategy, a potential response to a situation in which the scope to alter either the world or oneself is limited. Love (which, we will see, should not be restricted to romantic love) offers what in Bourdieu's view is most desirable: justification for existing as one does. It grants the kind of recognition and justification that he ordinarily suggests is provided only by the state, which otherwise 'alone has the power to justify you, to liberate you from facticity, contingency and absurdity’ (1990b: 196; 2000a: 245). To make this argument I detour through several peculiar texts, what are mostly literary commentaries of Bourdieu. While these have been described as exceptional to his sociological approach, I propose that within them we can unearth a logic that is not only consistent with this approach, but that makes genuine contributions to it. That is, these apparent digressions enabled Bourdieu to form arguments that would likely not have been developed in their absence.

We must take a preliminary detour through some scattered comments of another author, JeanPaul Sartre, from whom Bourdieu directly takes his conception of love. In his War diaries, 
Sartre develops an approach to love that has its foundation in 'feeling oneself justified for existing' (Sartre 1984: 261). Outside this experience of being loved, humans find themselves 'worried about that unjustified protuberance that [is] existence' (p.261). Those not loved feel themselves merely contingent, and so Sartre notes of himself that what most frequently led him into a romantic affair was 'the need to appear to some consciousness as "necessary" - in the same way as a work of art' (p.261). Bourdieu first adopts this Sartrean construal in his comments on love in Distinction:

Just as the art-lover finds a raison d'être in his discovery, which seems to have been waiting for all eternity for the discoverer's eye, so lovers feel "justified in existing”, as Sartre puts it, "made for each other”, constituted as the end and raison d'être of another existence entirely dependent on their own existence, and therefore accepted, recognized in their most contingent features...[and] legitimated in the arbitrariness of a way of being and doing. (1984: 243)

In his introduction to it here, Bourdieu sketches the dual meaning of the formulation, 'justified in existing'. While love functions, as Sartre suggests, to justify generically, it also functions to justify specifically: in loving another, one affirms the other's worth qua occupant of a specific social position. In so doing, assuming that the partners share a similar social background, one affirms one’s own particular existence, since '(l)ove is also a way of loving one's own destiny' (p.243). Because love is another act of knowledge, predicated on the agent's knowing who is likely to reciprocate her affection, by choosing a partner whom she feels to be 'made for' her, she offers practical assent to her destiny.

The paradigmatic form of this assent in Bourdieu's oeuvre is 'amor fati', in which one comes to 'accept, and even love' the objective limits internalized in the form of habitus (1984: 244). Amor fati constitutes the prism through which Bourdieu (2012 [1995]) interprets a poem of 
Guillaume Apollinaire ('Automne malade’), in what one commentator has described as an 'enigmatic text' (David 2012). The text is enigmatic, David argues, because Bourdieu appears to abandon his sociological approach to literature, adopting instead an earnest interpretive posture, and so evincing a 'relative indifference...towards his own epistemological principles' (p.126). Macé (2011: 170) adds that the piece 'is astonishingly free of sociological stakes'. In the commentary, Bourdieu focuses on how the narrator of the poem, speaking from the perspective of a future already realized, both pronounces to the season, autumn, its 'fate' (ie, its own passing, its 'death') and urges it to embrace and love this fate:

The poet pronounces the fatum, but also proffers an exhortation to amor fati. From the future anterior of prophesy, he jumps suddenly, at the beginning of the stanza, to the imperative. 'Die’, accept death, learn how to die. (Bourdieu 2012: 132)

Since, in Bourdieu's reading, Apollinaire depicts autumn as exemplifying the transitory, to love autumn, as the poem suggests ('Autumn, ill and adored'), is to love autumn precisely because it is transitory - because it is 'ill' and will expire:

What he loves in autumn is the death of autumn.... To love autumn, the most seasonal of seasons ('oh season'), is to attain amor amoris fati, the ultimate form of amor fati. It is to love in the world all that is fleeting, fragile, elusive, the Heraclitean flux and the fluidity of time passing, of the days and the loves which fly by. (pp.133-134)

I wish to suggest, in contradistinction to David, that despite this lyricism the text is consistent with Bourdieu's sociological thinking, especially as it mobilizes and clarifies several of his claims, expressed elsewhere, concerning ageing and necessity. To love the passing of time here is to affirm the gradual contraction of 'lateral possibles', otherwise known as social ageing (1987). It is to affirm one’s 'present and potential position in social space' (2000a: 
184) and to render actual the 'necessity' that is immanent in the relation between habitus and the social world. It is only immanent until it is actively brought to bear. Unlike the passing of the seasons, regulated by a meteorological cycle, the necessity that social ageing expresses is better described as actively accomplished than as simply undergone. Just as 'practice is not in time but makes time' (2000a: 206), so one brings about one's own 'fate' by the irreversible investments one makes. Thus it is significant that, within the poem, autumn be personified, that it be treated as if it has agency.

By reading this commentary alongside Bourdieu's analysis of Flaubert's Sentimental education, we can detect the sociologist proposing here an exhortation to necessity analogous to that of Apollinaire. What Bourdieu reads as Apollinaire's 'joyful acquiescence to time' (2012: 134) is detectable, a contrario, in his analysis of Flaubert’s protagonist, Frédéric. Frédéric demonstrates by his conduct the case of somebody artificially avoiding acquiescence, attempting to stave off necessity by indefinitely postponing the closing off of possibles. By failing to commit to any one of the possibles on offer to him, Frédéric exhibits the misery of seeking to escape the passing of time, of failing 'to accept growing old' (1987: 87). As Macé writes, the Bourdieu who saw in amor fati something irretrievably odious seems also to detect something redeemable therein. She states that it is 'as if Apollinaire permitted him to affectively and actively re-grasp the experience of necessity, and offered him a way of living a little differently the principal...idea of his own thought' (2011: 171).

An explicit exhortation to necessity can be found in the last of the pieces under consideration: his commentary on French poet Francis Ponge (Bourdieu 1986). The commentary, which Bourdieu entitles 'Nécessiter' ('To necessitate'), is likewise inflected with an uncharacteristically literary mode of expression that permits Bourdieu certain formulations that would be unavailable to him otherwise. In the text, Bourdieu proposes that the value of Ponge's work lies in his ability to 'rediscover' the necessity of things by positing the mutual 
absorption of subject and object, thus overcoming the subject-object divide in which visual metaphors remain trapped. The paradigm of such a relation, in which the object becomes absorbed as one absorbs oneself in it, is taste, 'the most sensual, sensualist, materialist sense' (p.347).

Bourdieu asks the question in this commentary whether one can, following Ponge, not merely absorb oneself in, and necessitate, things, but also people: 'To necessitate things; more difficult to generalize. To necessitate men?' (p.348). In fact, humans can be necessitated, and one absorbs oneself in the other by the 'forgetting of self' that Bourdieu above sees as characteristic of the ideal interview situation. The logic underlying the necessitating of a person, like an interview subject, is analogous to that underlying the necessitating of a thing like a work of art. Specifically, claiming that sociological analysis preserves love of an artwork because it reveals its necessity, Bourdieu notes that this is accomplished by uncovering the 'singular necessity’ of the work (Bourdieu 1996: xix). Here he cites Spinoza’s phrase, amor intellectualis Dei (intellectual love of God), which signifies for the latter the love that comes from the knowledge of one’s total dependence on God. By a play on words, this is adapted here to an amor intellectualis rei (intellectual love of the thing - in this case, the work of art), conveying the idea that one loves the work by virtue of an active surrender to it and its 'singular necessity'. Thus, by 'necessitating' the work, restoring it to, rather than tearing it from, its conditions of possibility, one comes to love it.

The singular necessity of the work of art is determined by uncovering its 'informing formula, its generative principle, its raison d'être' (1996: xix). In an analogous manner, the act of necessitating others, of discovering their singular necessity, is generated by a 'comprehension' of them, this term pointing to both an understanding and a figurative absorption of the other: 
this understanding [compréhension] implies no empathy, but a kind of intellectual enjoyment [jouissance] (amor intellectualis), very close to the aesthetic pleasure of coinciding with the law of the work, which is born of the lively sentiment of the raison d'être, of the necessity that a man has, if not in existing, at least in existing as he does. (1986: 348)

By necessitating the other, one offers her a reason for being what she is. In doing so, one gives a sociological response to the generic, existential demand to rescue the other from 'the insignificance and contingency of an existence without necessity’ (Bourdieu 2000a: 240). Yet love need not be reducible to the sentiment of being loved, which Sartre limited himself to exploring. As Bourdieu's post-script to Masculine domination would have it, loving another at the same time that one is loved furnishes the opportunity for what in this conception is ultimately desired: 'Mutual recognition, exchange of justifications for existing and reasons for being' (2001: 112). While loving another to whom one is otherwise socially 'destined' figures as an example of love as 'domination accepted' (p.109), even in such a case one profits from the possession of a specific and autonomous form of symbolic capital. The 'elementary social unit' that is the loving dyad operates, Bourdieu asserts, with 'a powerful symbolic autarky', and owing to the investment of those contained therein, is 'endowed with the power to rival successfully all the consecrations that are ordinarily asked of the institutions and rites of "Society"' (p.112). The loving dyad, then, offers in another form benefits denied to those whom the state does not recognize.

\section{Notes}

${ }^{1}$ Bourdieu’s manner of expression here, echoing Foucault, is deliberate. He proceeds to dispute any purported polar opposition between himself and Foucault, noting that while '[i]t's 
true that [Foucault] accentuated the dynamic, open side [of the body] more than me', they shared an animus toward personalist philosophy and a defatalizing ethos (2000b: 13).

\section{References}

Benson, H. H., (2000), Socratic Wisdom: The Model of Knowledge in Plato's Early Dialogues, New York: Oxford University Press.

Bohman, J., (1999), ‘Practical Reason and Cultural Constraint: Agency in Bourdieu’s Theory of Practice', in Shusterman, R. (ed), Bourdieu: A Critical Reader, Malden: Blackwell Publishers: 129-152.

Boltanski, L., (2011), On Critique: A Sociology of Emancipation, Cambridge: Polity Press.

Bourdieu, P., (1974), ‘Avenir de Classe et Causalité du Probable’, Revue française de sociologie, 15 (1): 3-42.

Bourdieu, P., (1979), 'Les Trois Etats du Capital Culturel', Actes de la Recherche en Sciences Sociales, 30: 3-6.

Bourdieu, P., (1984), Distinction: A Social Critique of the Judgement of Taste, Cambridge, MA: Harvard University Press.

Bourdieu, P., (1986), 'Nécessiter’, Cahier de l’Herne, 51: 434-437.

Bourdieu, P., (1987), 'The Invention of the Artist’s Life’, Yale French Studies, 73: 75-103.

Bourdieu, P., (1990a), The Logic of Practice, Cambridge: Polity Press.

Bourdieu, P., (1990b), In Other Words: Essays Towards a Reflexive Sociology, Stanford, CA: Stanford University Press.

Bourdieu, P., (1991), 'Contre les Divisions Scolastiques’, L’université au Défi de au Culture, Toulouse: ADDOCC Midi-Pyrénées: 31-57.

Bourdieu, P., (1993), Sociology in Question, London: Sage. 
Bourdieu, P., (1996), The Rules of Art: Genesis and Structure of the Literary Field, Cambridge: Polity Press.

Bourdieu, P., (1999), 'Understanding', in Bourdieu, P. (ed), The Weight of the World: Social Suffering in Contemporary Society, Stanford: Stanford University Press: 607-626.

Bourdieu, P., (2000a), Pascalian Meditations, Stanford: Stanford University Press.

Bourdieu, P., (2000b), ‘À Contre-Pente (Entretien Avec Philippe Mangeot)’, Vacarme, 14: 414.

Bourdieu, P., (2001), Masculine Domination, Cambridge, UK: Polity Press.

Bourdieu, P., (2002), Si le monde social m'est supportable, c'est parce que je peux m’indigner, La Tour d'Aigues: Éditions de l’Aube.

Bourdieu, P., (2008), Political Interventions : Social Science and Political Action, London: Verso.

Bourdieu, P., (2012), ‘Apollinaire, Autumn Ill’, Paragraph, 35 (1): 131-136.

Bourdieu, P., (2015), Sociologie Générale: Cours au Collège De France 1981-1983, Paris: Seuil.

Bourdieu, P. and Eagleton T., (1992), 'Doxa and Common Life', New Left Review, 191: 111121.

Bourdieu, P. and Wacquant L. J. D., (1992), An Invitation to Reflexive Sociology, Chicago: University of Chicago Press.

Breuer, J. and Freud S., (2001), Studies on Hysteria, London: Vintage.

Burnyeat, M. F., (1980), 'Socrates and the Jury: Paradoxes in Plato’s Distinction between Knowledge and True Belief', Proceedings of the Aristotelian Society, 54: 173-191.

Burnyeat, M. F., (2012), Explorations in Ancient and Modern Philosophy: Volume 2, Cambridge: Cambridge University Press.

Claudel, P., (1969), Poetic Art, Port Washington, NY: Kennikat Press. 
Darmon, M., (2016), 'Bourdieu and Psychoanalysis: An Empirical and Textual Study of a Pas de Deux', The Sociological Review, 64: 110-128.

David, J., (2012), 'On an Enigmatic Text by Pierre Bourdieu’, Paragraph, 35 (1): 115-130.

Day, J. M., (1994), ‘Glossary’, in Day, J. (ed), Plato’s Meno in Focus, London: Routledge: $250-251$.

Elias, N., (1994), The Civilizing Process, Malden: Blackwell Publishing.

Fourny, J.-F., (2000), ‘Bourdieu’s Uneasy Psychoanalysis’, SubStance, 29 (3): 103-112.

Frangie, S., (2009), 'Bourdieu’s Reflexive Politics: Socio-Analysis, Biography and SelfCreation', European Journal of Social Theory, 12 (2): 213-229.

Gaulejac, V., (1997), ‘Clinical Sociology and Life Histories’, International Sociology, 12 (2): 175-190.

Gaulejac, V., (2003), ‘De l’Inconscient chez Freud à l’Inconscient chez Bourdieu’, in Corcuff, P. (ed), Pierre Bourdieu: Les Champs De La Critique, Paris: Bibliothèque Centre Pompidou: 75-98.

Grene, M., (1977), ‘Tacit Knowing: Grounds for a Revolution in Philosophy’, Journal of the British Society for Phenomenology, 8 (3): 164-171.

Henley, N., (1977), Body Politics: Power, Sex, and Nonverbal Communication, Englewood Cliffs, N.J.: Prentice-Hall.

Hilgers, M., (2009), 'Habitus, Freedom, and Reflexivity’, Theory \& Psychology, 19 (6): 728755.

Latour, B., (2005), Reassembling the Social: An Introduction to Actor-Network-Theory, Oxford: Oxford University Press.

Macé, M., (2011), Façons de Lire, Manières d’Etre, Paris: Gallimard.

Martin K. A., (1998), 'Becoming a Gendered Body: Practices of Preschools’, American Sociological Review, 63 (4): 494-511. 
Mauger, G. and Pinto L., (1994), Lire les Sciences Sociales, Paris: Belin.

Merleau-Ponty, M., (1963), The Structure of Behavior, Boston: Beacon Press.

Merleau-Ponty, M., (2012), Phenomenology of Perception, New York: Routledge.

Nehamas, A., (1994), ‘Meno’s Paradox and Socrates as a Teacher’, in Day, J. M. (ed), Plato’s Meno: In Focus, London: Routledge: 221-248.

Plato, (1997), Complete Works, Indianapolis: Hackett Publishing Company.

Rancière, J., (2003), The Philosopher and His Poor, Durham, NC: Duke University Press.

Rancière, J., (2012), La Leçon d’Althusser, Paris: La Fabrique.

Sartre, J.-P., (1984), War Diaries: Notes from a Phoney War, November 1939 - March 1940, London: Verso.

Scott, D., (2006), Plato’s Meno, Cambridge, UK: Cambridge University Press.

Steinmetz, G., (2013), ‘Toward Socioanalysis: The “Traumatic Kernel” of Psychoanalysis and Neo-Bourdieusian Theory’, in Gorski, P. S. (ed), Bourdieu and Historical Analysis, Durham, NC: Duke University Press: 108-130.

Witz, A., (2004), ‘Anamnesis and Amnesis in Bourdieu’s Work: The Case for a Feminist Anamnesis', The Sociological Review, 52: 211-223. 


\section{University Library}

\section{- M M I N E R VA A gateway to Melbourne's research publications}

Minerva Access is the Institutional Repository of The University of Melbourne

Author/s:

MEAD, G

Title:

Forms of knowledge and the love of necessity in Bourdieu's clinical sociology

Date:

2017-11-01

Citation:

MEAD, G. (2017). Forms of knowledge and the love of necessity in Bourdieu's clinical sociology. The Sociological Review, 65 (4), pp.628-643. https:// doi.org/10.1177/0038026116674883.

Persistent Link:

http://hdl.handle.net/11343/123658

License:

Unknown 